\title{
Effect of changing groundwater level on shallow landslide at the basin scale: a case study in the Odo basin of South Eastern Nigeria
}

\author{
Christopher Uchechukwu Ibeh \\ Newcastle University Newcatle upon Tyne, United Kingdom \\ cuibeh@gmail.com
}

\begin{abstract}
This study investigated the effect of changing groundwater level on the propagation and continued expansion of gully erosion and landslide in the Odo River sub basin (a major section of the Agulu-Nanka gully erosion and landslide complex located in south eastern Nigeria). A novel modified deterministic approach, loosely coupled stability (LOCOUPSTAB) framework which involves the development and linkage of groundwater recharge model, groundwater model (MODFLOW) and slope stability model (using Oasys slope, a program for stability analysis by limiting equilibrium) was used to determine the possibility of improving the stability of the study area. For the modelled scenario, reducing groundwater level through pumping from three boreholes at $300 \mathrm{~m}^{3} /$ day over one year, resulted in an increase in proportional change in factor of safety by an average 0.56 over the Odo river sub-basin. A stability risk map was also developed for the sub-basin. Useful information can be obtained even based on imperfect data availability, but model output should be interpreted carefully in the light of parameter uncertainty.
\end{abstract}

\section{KEY WORDS}

Landslide, deterministic approach, groundwater, Agulu-Nanka gully, LOCOUPSTAB, sustainability.

\section{INTRODUCTION}

Damages to settlements and infrastructure as well as human casualties caused by landslide are increasing worldwide (Singhroy et al., 2004; Neuhauser and Terhorst, 2007; Haque et al., 2016). On average landslide account for about $18 \%$ of all fatalities from natural disaster worldwide (Safaei et al., 2011). Landslide in developing countries are especially serious since more than $95 \%$ of all disasters and fatalities related to landslide, and mass movement in general, occur in developing countries and this is because environmental management and protection are harder to sustain in developing countries (Hansen, 1984; Chung et al., 1995; Temesgen et al., 2001; Howes et al., 2017).

Rainfall and pore water pressure changes may affect slope stability (Alonso et al., 2003; Dai et al., 2003; Zhang and Chen 2005; Conte and Troncone 2012; Wang et al. 2012; Liu and Li, 2015; Conte et al., 2018). Pore pressure changes in the form of groundwater level fluctuation and suction and this in turn is related to rainfall. Wu and Niu (2012) explored a method of predicting landslide deformation considering groundwater level based on the improved Kalmer filter method and demonstrated that it is theoretically feasible to use groundwater level to predict landslide. In Shikuko, Japan, groundwater flow modelling is used for effective 
implementation of landslide stability enhancement measures ( $W u$ and Niu 2012). On the other hand, Schiller and Wynne (2010) studied the effect of declining water levels on the stability of riverbank slope and showed that the pore water pressure profile does not change quickly with a change in water table depth, for soil with low permeability; this is also corroborated by Alonso et al., 2003, in their study of the influence of rainfall on the deformation and stability of over consolidated clay and delayed failure in over consolidated clay. The Odo river basin is overlain by a thick sandstone Formation and this allows for relatively better rainfall infiltration, which makes it susceptible to groundwater fluctuation.

Highly instrumented monitoring studies of groundwater level and how they affect landslide may reveal the connection between pore water pressure and landslide, funding for such a gigantic project may not come without some indication that the studies will latter pay-off. Especially in developing countries with meagre fund for research. Modelling is a preferred option to understand the feasibility of remediation options. Simulating groundwater changes and its impact on the stability of the landmass is the focus of this research.

A review of current approaches to the study of landslide susceptibility and predictive modelling is given in Safaei et al., 2011. Based on his study, there are four major approaches, namely: Inventory, Heuristic, Statistical and Deterministic (physical) approaches

Inventory approach is the simplest approach to landslide study in which an inventory of landslide is mapped either by collecting historical information of individual landslide events or by remote sensing using satellite image and aerial photographs coupled with field survey using Global positioning system. This approach is based on probabilistic approach with the assumption that occurrence of landslide in the past is a good indication of the likelihood of future occurrence. However, this assumption may not be true, and most landslide information are incomplete both in space and time since records are most often biased to mass movement that affect infrastructure. The use of this method in the Odo River Basin is further limited because records of landslide events are not comprehensive enough for such study.

Heuristic approach is a qualitative method which is based on evaluating actual landslides by comparing geomorphological and geological characteristics. An example is the SMORPH model by Shaw and Johnson 1995 -cited in Safaei et al., 2011 which classify hill slope as high, moderate, or low landslide hazard based on their local topographic slope and curvature. However, this method is strongly dependent on the experience of the surveyors carrying out the study and its usefulness may not be feasible in complex landslide and gully erosion setting like in the Odo River Basin.

Statistical approach assumes that the prediction of future landslide areas can be assessed by measuring a combination of variables that has led to landslide occurrence in the past. With this method, terrain units or grid cells are transformed to values of probability, degree of certainty or the plausibility that the respective terrain units may contain or can be subject to a particular landslide in the future. Various statistical techniques such as Bivariate or Multivariate techniques abound, and Artificial Neural networks may be used. However, statistical approach does not indicate the mechanisms that control slope failure, and neither does it give a mechanical meaning and there are limitations to extrapolation beyond the study area (Lee et al., 2004; Safaei et al., 2011). Statistical approach has been used in the study area. Ofomata 1982 - cited in Igwe (2012) - tried using multiple regression with the environmental factors of vegetation, climate, soil and anthropogenic factors as variables to predict gully 
erosion in south-eastern Nigeria; Igwe (2012) and Anejionu et al., (2013) used the Revised Universal soil loss Equation (RUSLE) and Igbokwe et al., (2008) used the Universal soil erosion model to delineate erosion prone areas on a state scale. The use of both the Universal soil loss equation and the Revised Universal soil loss equation, though can predict rill erosion however, in addition to the limitations of the statistical method outlined above, they cannot tell much about the reason for the expansion of gullies - the major form of erosion in the study area- neither can they explain the landslide (which is also known to occur in the area) process and mechanism.

For deterministic approach, landslide hazard is determined using slope stability method by calculating factor of safety values. They provide quantitative information on landslide hazard which can be used to quantify risk. Their application with steady state or transient model for hill slope hydrology may be used to assess scenarios of potential instability under changing environmental or climatic conditions. On the other hand, the deterministic approach is data demanding. This approach was used in this study because it accounts for the mechanisms that control stability and provides quantitative information on landslide hazards. The approach may be further advanced as coupled numerical simulation in areas with detailed hydromechanical properties and this take into consideration pre, sin and post failure observation. Table 1 below is a list of deterministic approaches used by researchers on a watershed scale (modified from Safaei et al., 2011).

\section{Table 1: List of Deterministic approaches}

\begin{tabular}{|c|c|c|c|}
\hline $\begin{array}{l}\text { DETERMINISTIC } \\
\text { APPROACHES }\end{array}$ & DESCRIPTION & RESEARCHER & DATE \\
\hline CHASM & Combined hydrology and stability model & $\begin{array}{c}\text { Anderson and Lloyd, 1991; Anderson } \\
\text { et al., 1996) }\end{array}$ & 1991 \\
\hline LISA & Level 1 Stability Model & Hammond et al & 1992 \\
\hline SHALSTAB & Shallow Landslide Stability Model & $\begin{array}{l}\text { Montgomery and Dietrich (1994, } \\
\text { 1998) }\end{array}$ & 1994 \\
\hline SMORPH & Slope MORPHology & Shaw and Johnson (1995) & 1995 \\
\hline DSLAM/IDSSM & $\begin{array}{c}\text { Distributed Shallow Landslide Model/Integrated } \\
\text { Landslide Dynamic Slope Stability Shallow Landslide } \\
\text { Model }\end{array}$ & Wu and Sidle (1997) & 1997 \\
\hline SINMAP & Stability Index Mapping & Pack et al., $(1998,2001)$ & 1998 \\
\hline Miller \& Sias Model & Distributed integrated Landslide model & Miller \& Sias (1999) & 1998 \\
\hline SHETRAN & System Hydrology European TRANsport & $\begin{array}{l}\text { Ewen et al.,2000 } \\
\text { Birkinshaw et al., } 2010\end{array}$ & 2000,2010 \\
\hline TRIGRS & $\begin{array}{c}\text { The Transient Rainfall Infiltration and Grid- based } \\
\text { Regional Slope Stability }\end{array}$ & $\begin{array}{l}\text { Iversion (2000) and and extended by } \\
\text { Baum et al. (2002) }\end{array}$ & 2000,2002 \\
\hline PROSTAB & Probability of STABility PCRaster GIS package & Van Beck (2002) & 2002 \\
\hline $\begin{array}{l}\text { TRIGRIS- } \\
\text { unsaturated }\end{array}$ & $\begin{array}{l}\text { The Transient Rainfall In filtration and Grid- regional } \\
\text { Slope-stability }\end{array}$ & Savage et al., 2004 & 2004 \\
\hline PISA & Probability infinite slope analysis & Heaneberg (2004) & 2004,2005 \\
\hline
\end{tabular}

In this study, a modified deterministic approach is presented: the loosely coupled stability model (LOCOUPSTAB model) see section 2 for more details. It is however important to note that to analyse the post-failure stage and run-out of a landslide, it is necessary to use advanced numerical technique (Crosta et al., 2003; Yerro et al., 2016; Conte et al., 2019).

This paper examines for the first time, the slope stability analysis of the Odo river sub-Basin of South Eastern Nigeria and assesses the impact of changing groundwater level on the stability of the area using a novel modified loosely coupled stability model framework (LOCOUPSTAB) developed in this study. A conceptual model of the stability problem was first presented and then studied using the LOCOUPSTAB. A groundwater numerical model was developed using MODFLOW and Oasys slope (a program for stability analysis by limiting 

1a)

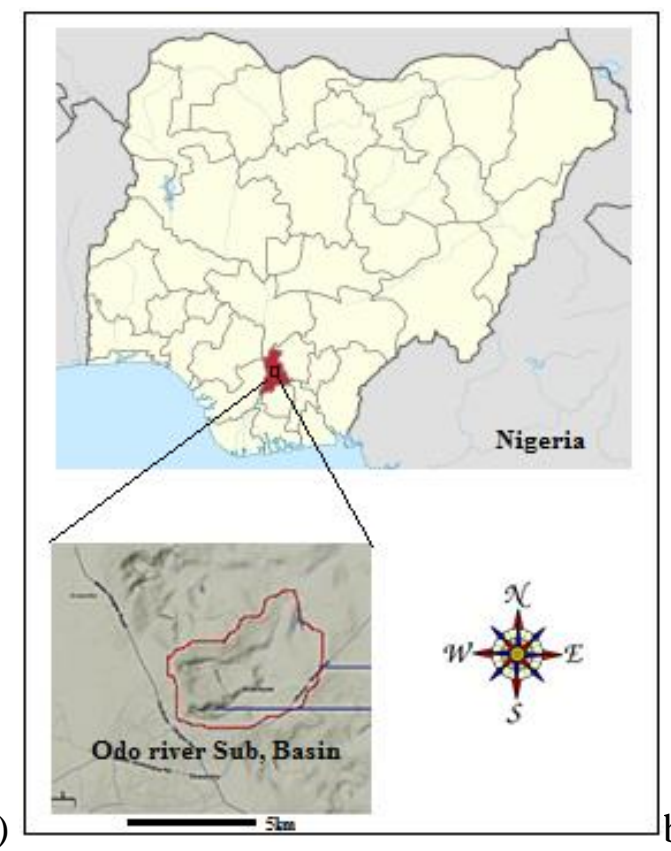

\subsection{Stydy Area} habitation (Simpson et al., 1999). equilibrium) was used for the slope stability analysis. Finally, a risk map was developed for the first time in the area using output from the stability analysis and Geographic information system (GIS) based on proportional change in factor of safety.

The Odo River sub-basin is a part of the Agulu-Nanka gully complex located in the Anambra Basin, south eastern Nigeria. It covers an area of approximately $30 \mathrm{Km}^{2}$ and lies between longitudes $6^{0} 2^{\prime} 0^{\prime \prime}$ and $6^{0} 4^{\prime} 0^{\prime \prime}$ North and latitudes $7^{0} 3^{\prime} 0^{\prime \prime}$ and $7^{0} 7^{\prime} 30^{\prime \prime}$ East. The AguluNanka area is part of the Awka Orlu upland which forms a cuesta with the crest of the Cuesta at over 350m above sea level at Isuofia and falls steeply eastwards into the Mamu River plains and gently westwards to the Idemili River lowlands (see Figures 1a and 1b below) and extensive gully formation has given rise to treeless systems of knife edge ridges and intervening steep sided gorges typical of bad lands, Simpson et al. (1999). The development and continued expansion of thousands of active gully erosion and landslide sites in South Eastern Nigeria have caused the previously densely forested rolling terrain to be dangerous for human
Figure 1a) Locationof the study area, b) Topographic map with vertical electrical sounding (VES) locations.

\subsection{Geology of the Area}

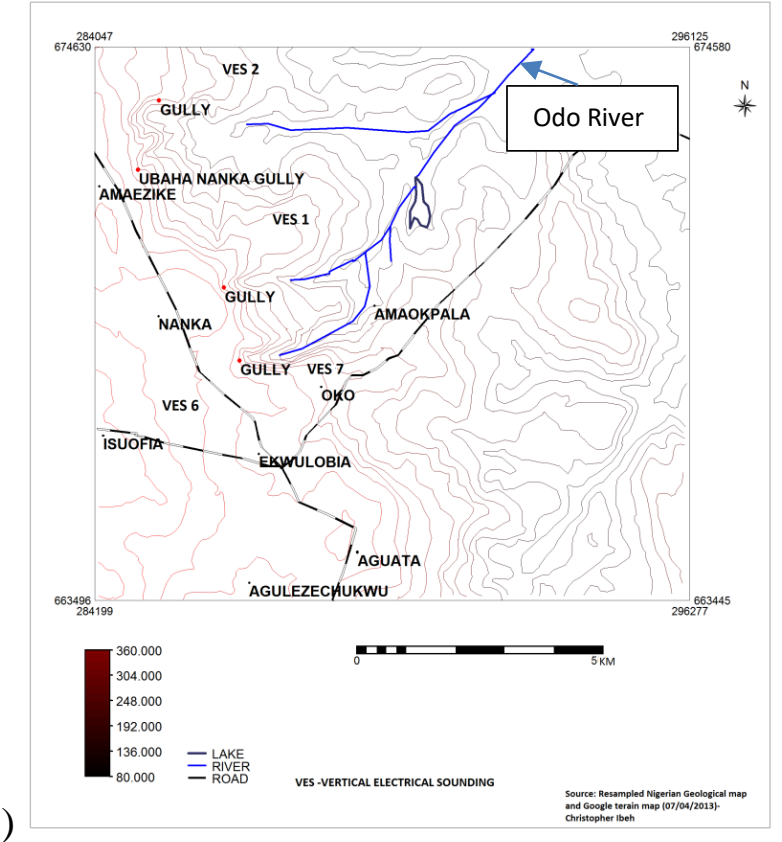

The study area is within the Anambra Sedimentary Basin. It is bounded on the west by the Precambrian Basement complex rocks of Western Nigeria and on the East by the Abakaliki Anticlinorium, to the south it is bounded by the Northern limit of the present-day Niger Delta while the Northern boundary is not well defined, Uma and Onuoha (1997). The Nanka Sandstone Formation (Eocene) and the Imo Shale Formation (Paleocene) are the geologic units in the study area. According to Egboka and Nwankwo (1984), the heavily gullied Nanka Sandstone Formation -which is overlain in some other places by the Lignite Clay seams of the Ogwasi-Asaba Formation (Oligocene)- is a sequence of unconsolidated, poorly sorted and 
poorly cemented sandstone about 330m thick and it consists of distinct units of sand, shalesiltstone and finely laminated shale/clay unit with specs of mica, pyrite and gypsum in some places( see figures $2 \mathrm{a}$ and $\mathrm{b}$ below). Egboka and Nwankwo (1984) showed that the deposit exhibits a systematic pattern of alternating Cross-bedded sands and dark grey shales with the sand horizon consistently thicker than the shale-siltstone; the strata have a low angle of about $9^{0}$ West. The Imo Shale Formation underlies the Nanka Sandstone Formation. It is predominantly shale and consists of dark grey to bluish grey shales, siltstone, mudstone, Ironstone and sandstone lenses Egboka and Nwankwo (1984). Unlike the Imo Shale unit, the unconsolidated Nanka formation is susceptible to gully erosion.
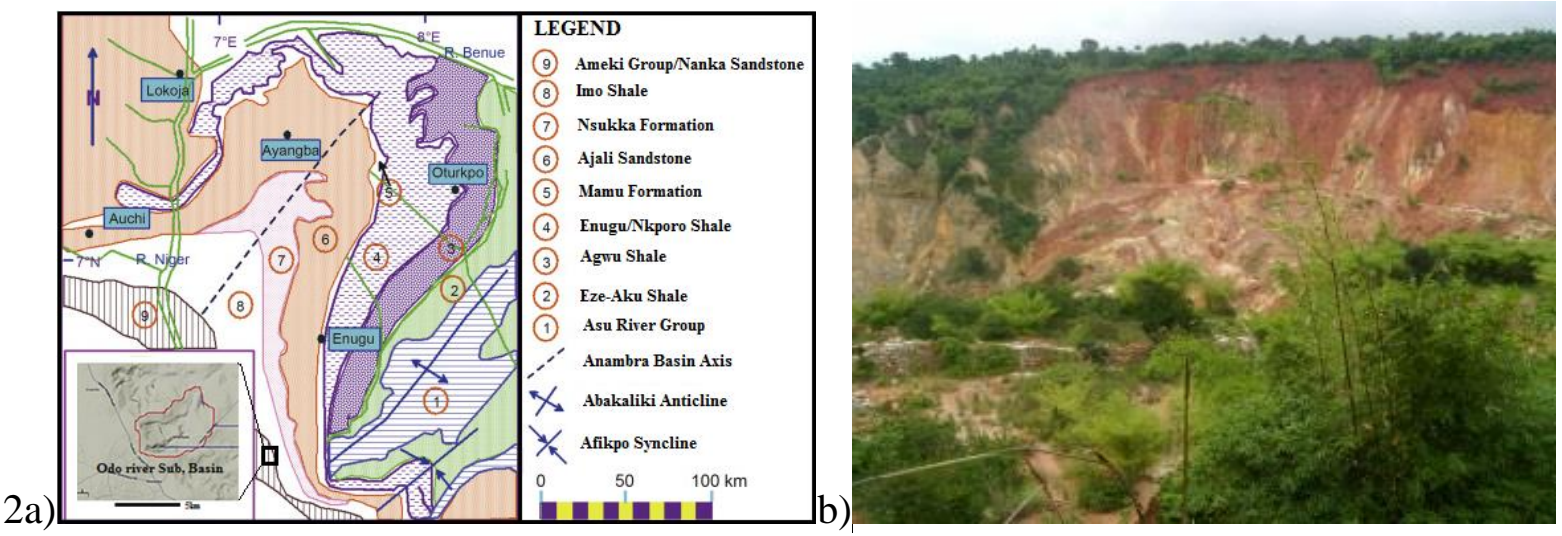

Figure 2a) Diagram showing the location of the Anambra Basin and its lithologic sequence modified form Bankole and Ola-Buraimo (2017); b) picture of a typical gully section of the area.

\subsection{Hydrogeology}

Studies by Egboka and Nwankwo (1984) and Okoro et al. (2010) show that the Agulu -Nanka complex is drained by many rivers such as the Idemili, Nkisi, Mamu,Odo, Crashi, Uchu and Aghomili. Numerous lakes such as Agulu, Ulasi and Otiba occur in the area. Furthermore, Agulu -Nanka gully complex comprises a series of aquifers separated by aquitards that combine to form multi aquifer systems of about $300 \mathrm{~m}$. The surface and regional groundwater divide runs approximately north south of the area while the Imo shale forms the base (see Figure 2c below) of the Nanka Formation. The unsaturated zone in some places may be more than $50 \mathrm{~m}$ thick during the dry season but decreases towards the water courses and the edges of the numerous lakes with effluent seepages and springs discharge from the sand- clay boundary and from incipient fractures in the upper reaches of the gully wall, Okoro et al. (2010). 


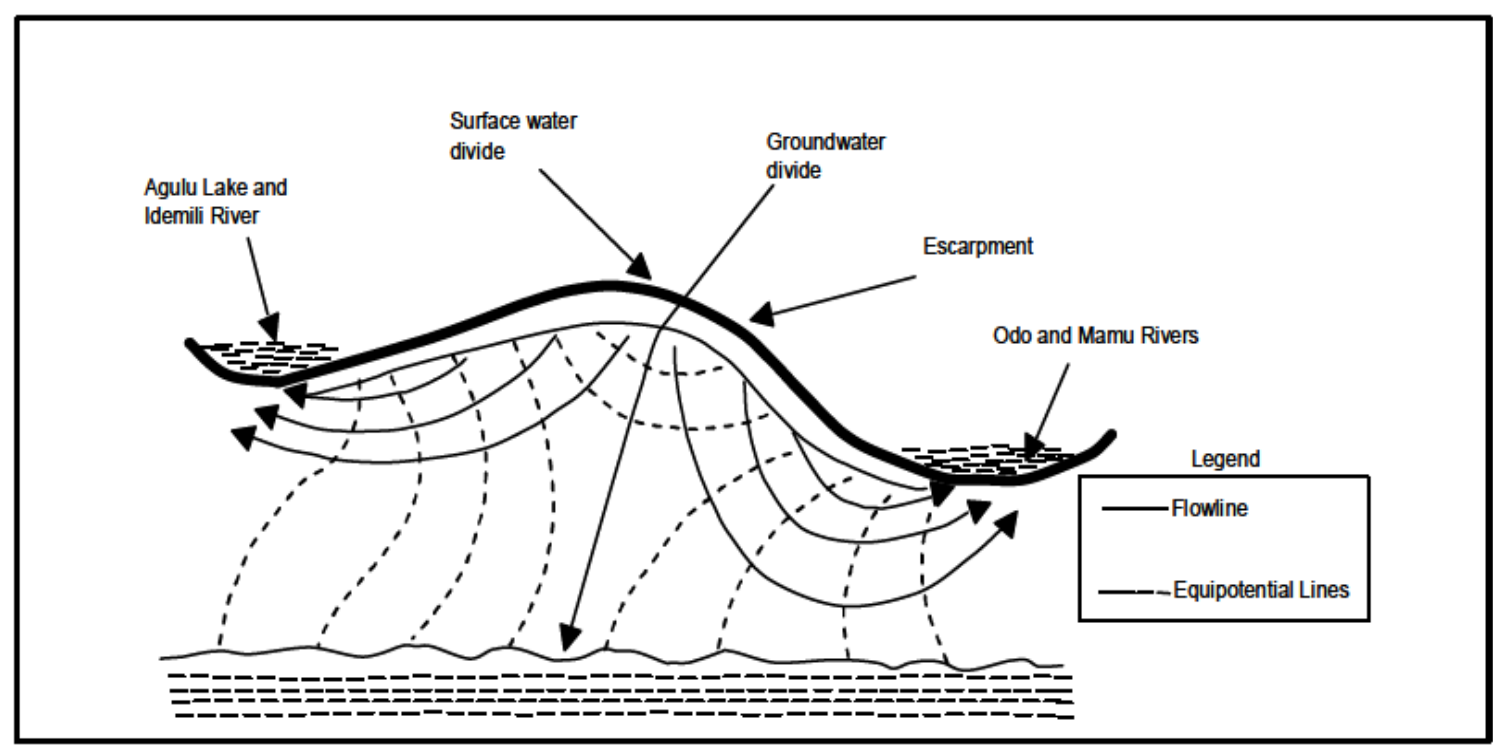

168

169

Figure 2c: Physiography as well as surface and groundwater divide in Agulu- Nanka (Modified from: Egboka and Nwankwo 1984 \& Okoro et al. 2010)

\section{METHODOLOGY:}

Deterministic approach was used in this study using the LOCOUPSTAB model framework. The LOCOUPSTAB model framework is an integration of groundwater recharge, groundwater flow, and slope stability models. The framework (figure 3) begins with the development of a conceptual model of the problem domain (the basin area). This is then followed by the collation of spatial hydrologic parameters of the study area to produce a typology map (with the use of ILWIS GIS Software) as well as statistical analysis of some meteorological data to determine the best time frame to model and the effect of rainfall on gully erosion and landslide. The modified environmental Agency spatial recharge model was used to determine the spatial groundwater recharge in the area which served as the input recharge for the groundwater flow model. Furthermore, the groundwater levels output was input into. OASYS SLOPE ${ }^{\circledR}$ (2012) Stability software. This is followed by a systematic variation of the groundwater level simulated by pumping from wells assumed to be drilled within the groundwater model domain and the change in factor of safety determined. The focus was on the proportional change in factor of safety and not on the absolute value of the factor of safety this was because the later may not be obtainable to a high degree of accuracy consequent on the limitations arising from the assumptions that have been made in the modelling process. a). It is important to note that to analyse the post-failure stage and run-out of a landslide, it is necessary to use advanced numerical technique (Crosta et al., 2003; Yerro et al., 2016; Conte et al., 2019). 


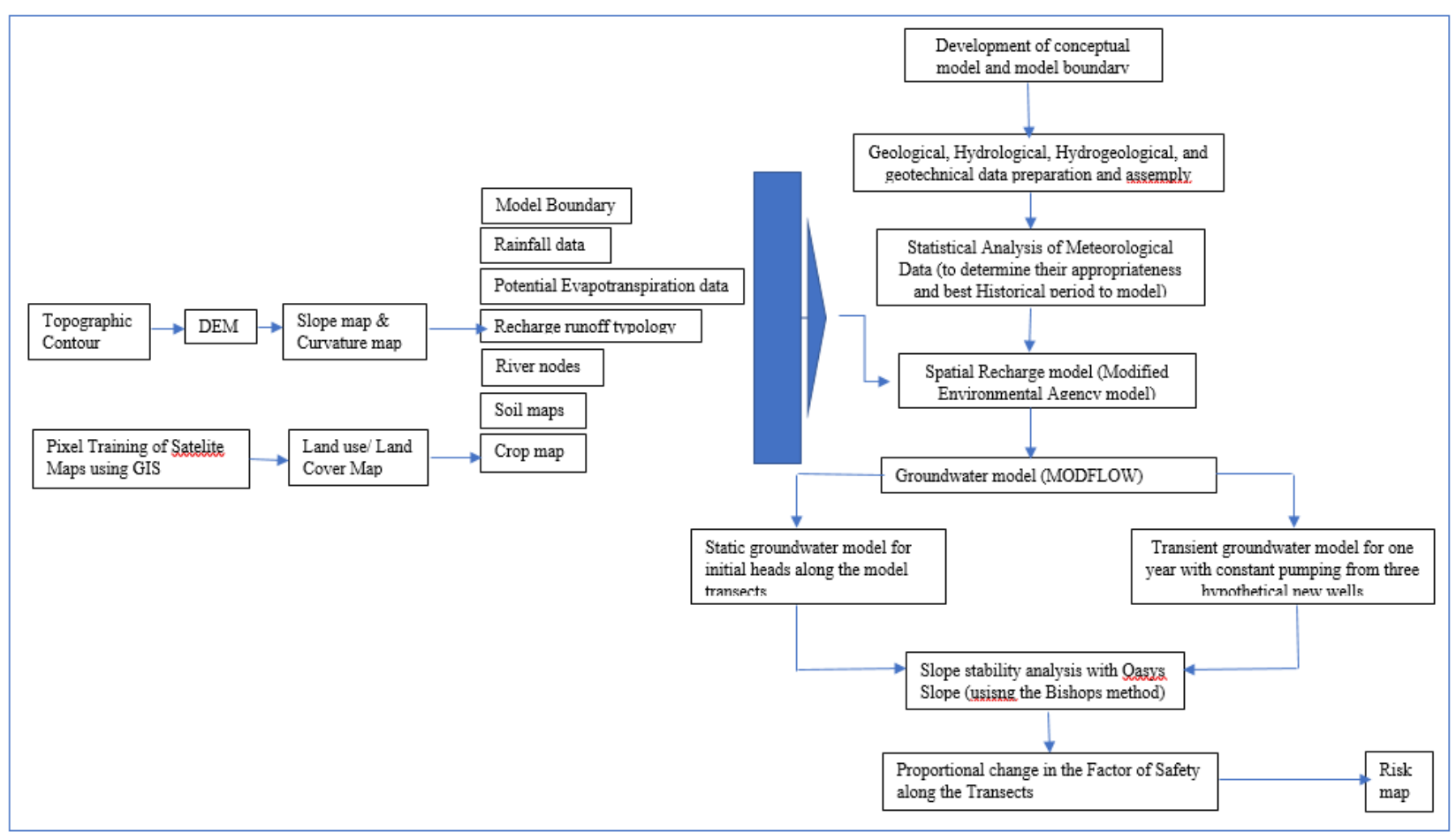

Fig 3: LOCOUPSTAB model framework

\subsection{Case Study of the Odo River sub Basin}

Basic description of the case study area is presented in section 1.1 to 1.3 above. Details of the case study area in line with the LOCOUPSTAB model framework is presented below.

\subsection{Conceptual model}

Most of the landslide events in the Odo River Sub-Basin occur during the wet season. The diagram below (Figure 4) shows a hypothesised conceptual model of the trigger mechanism of landslide in the study area. This model shows that during rainfall, some water evaporates, some run off the earth surface carrying eroded sediment downslope into the Odo- River and the Oguta Lake - and silting these water bodies. Furthermore, the remainder of the rainwater infiltrates into the soil zone and percolates, recharging groundwater causing its level to rise. As the groundwater level rises, it results in an increase in pore water pressure which causes the reduction of the shear strength of the Nanka Sand. The Nanka Sand thereby disaggregates, forming piping condition at the base of the Awka- Orlu Cuesta. This creates tensional force with a downward drag. As the tension increases, cracks propagate upwards through the overlying sandy shale and laterite layers to the earth surface and with time, the driving force from the pore pressure as well as the weight of the rock mass exceeds the restoring force. This gives rise to downslope movement of the rock mass along a circular slip surface created down the tension crack. The cyclical pattern continues throughout the wet season, therefore propagating the spread of the gully and landslides. 


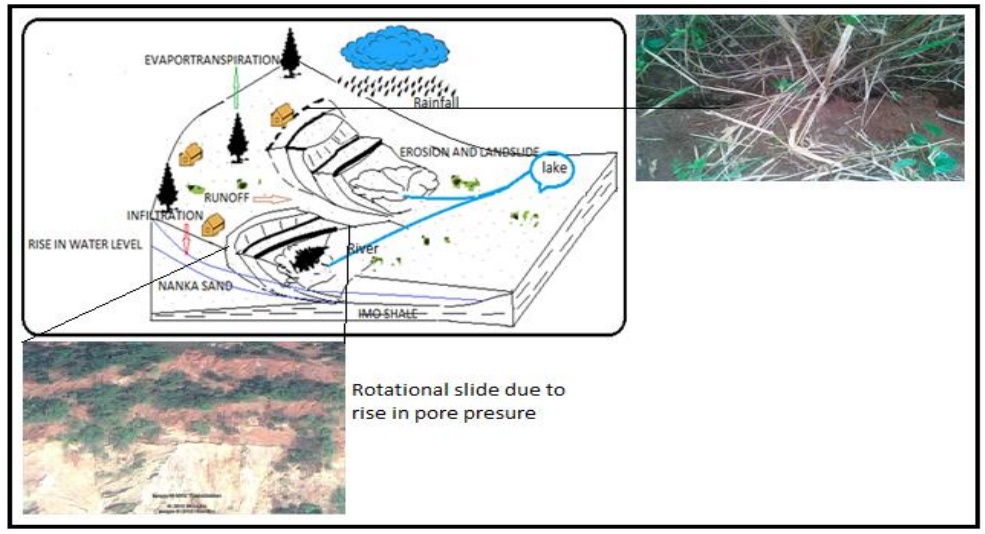

Figure 4: Conceptual model

It has been suggested that keeping the groundwater level low by pumping may significantly reduce the continued expansion of the menace in the Odo river sub-Basin. A Simulation of the experiment numerically using the LOCOUPSTAB Model framework is presented below.

\subsection{Model domain}

The model domain covers an area of $25.9 \mathrm{~km}^{2}$. To the east of the model domain is a lithologic boundary: the contact between the Imo Shale Formation and the Nanka Sand Formation (Figure 4) and to the north east corner of the domain is the Oguta Lake. To the west, it is bounded by a groundwater divide. On the other hand, the North and south boundaries are topographic boundaries, that is, areas of higher elevation within which surface water flow towards the Odo River. The domain was delineated in ARCGIS ${ }^{\circledR}$ with the $\mathrm{x}$ and $\mathrm{y}$ origin (that is, the lower left corner) of the grid frame at $284105.7 \mathrm{~m}$ and $665652.0 \mathrm{~m}$ respectively (these values are the Universal Transverse Mercator (UTM) geographic coordinate system, zone 32 Minna, Nigeria) of the origin. Their dimensions are $7084.0 \mathrm{~m}$ and $7992.6 \mathrm{~m}$ respectively. All cells outside the domain area delineated by the basin boundary ware rendered inactive.

\subsection{Spatial recharge model}

A modified UK Environment Agency special recharge model was used for recharge estimation. Running the UK Environment Agency recharge model required data sets with some spatial processing. Using ILWIS 3.0 ${ }^{\circledR}$ the Digital Elevation Model for the area was developed and the spatial analyst tool in ARCGIS $10.1^{\circledR}$ was used to prepare slope map, flow direction map, curvature map as well as soil map and all these were integrated using the Raster calculator and the Resample tools in ARCGIS ${ }^{\circledR}$ to delineate runoff/recharge typologies. Table 2 shows the data input into the spatial recharge model. Potential evapotranspiration was calculated using the Thornthwaite equation (Shaw 1994) derived for tropical region like south eastern Nigeria. The monthly mean temperature values used were obtained from the UK Meteorological Office website (2013).

Table 2: Data source for Environment Agency spatial recharge model of the Odo River Sub-Basin

\begin{tabular}{ll|}
\hline REQUIRED DATA & AVAILABLE DATA \\
\hline Surface Boundary of catchment & $\begin{array}{l}\text { ARCGIS® Shape file converted to a raster data with values of one for areas } \\
\text { within the boundary and zeros for areas outside the boundary created }\end{array}$ \\
\hline Grid & $\begin{array}{l}\text { Grid created in ARCGIS }(284300,665500,292100,673000, \text { X and Y UTM } \\
\text { coordinate of lower left corner followed by upper right corner respectively. }\end{array}$ \\
& 156 and 150 Number of columns and number of rows respectively \\
\hline Runtime & January 1993 to December 1995 \\
\hline
\end{tabular}




\begin{tabular}{|c|c|}
\hline \multicolumn{2}{|l|}{ METEOROLOGICAL DATA } \\
\hline Rainfall & $\begin{array}{l}\text { Daily rainfall data (1979-2005) of Onitsha regional weather station from the } \\
\text { Nigerian Meteorological Agency }\end{array}$ \\
\hline Potential Evapotranspiration & $\begin{array}{l}\text { Potential evapotranspiration data calculated with Thonthwaite method (Shaw } \\
\text { 1994) }\end{array}$ \\
\hline \multicolumn{2}{|l|}{ SOIL INFORMATION } \\
\hline Soil data & $\begin{array}{l}\text { Soil map from European digital archive of soil maps- } \\
\begin{array}{l}\text { (http://eusoils.jrc.ec.europa.eu/esdb_archive/ } \\
\text { eudasm/africa/lists/s1_cng.htm) }\end{array}\end{array}$ \\
\hline Land use & $\begin{array}{l}\text { Land use /land cover map developed in this study using LANDSAT image } \\
\text { and pixel training using ground control }\end{array}$ \\
\hline Crop data & Land use/ Land cover map developed in this study \\
\hline \multicolumn{2}{|l|}{ HYDROLOGICAL DATA } \\
\hline Location of surface water & $\begin{array}{l}\text { UDI Sheet } 301 \text { Topographic map (Nigerian Geological Survey Agency map } \\
\text { series) as well as the use of flow direction and flow accumulation analysis of } \\
\text { the Digital Elevation Model (DEM) in ARCGIS® }\end{array}$ \\
\hline Recharge and Runoff zones & Typology map developed in this study \\
\hline Topography & DEM developed in this study \\
\hline \multicolumn{2}{|l|}{ GEOLOGY AND HYDROGEOLOGICAL DATA } \\
\hline Geology & Published Geological map of the Nigeria Geological Survey Agency \\
\hline Groundwater abstraction - licenced & Not used \\
\hline Groundwater abstraction - Unlicensed & Not used \\
\hline \multicolumn{2}{|l|}{ ARTIFICIAL RECHARGE } \\
\hline $\begin{array}{l}\text { Sewage systems, sewage treatment works and storm } \\
\text { water overflows discharging to ground }\end{array}$ & Data not available (assumed to be zero) \\
\hline Soakaways from major roads & Data not available (assumed to be zero) \\
\hline
\end{tabular}

240 The output recharge model was zoned using the three recharge areas (Using the dominant

241 Runoff/Recharge Typology) and input into the groundwater model to simulate groundwater level.

\subsection{Groundwater model}

244 The numerical groundwater model was developed using Groundwater modelling system (GMS) which works based on MODFLOW (Anderson and Woessner, 1992)-

246 Groundwater flow equation:

$\delta / \delta \mathrm{x}(\mathrm{kx} \delta \mathrm{h} / \delta \mathrm{x})+\delta / \delta \mathrm{y}(\mathrm{kx} \delta \mathrm{h} / \delta \mathrm{y})+\delta / \delta \mathrm{z}(\mathrm{kx} \delta \mathrm{h} / \delta \mathrm{z})=\mathrm{ss} \delta \mathrm{h} / \delta \mathrm{t}-\mathrm{R}$ (Eq. 1)

Where: $\mathrm{Kx}, \mathrm{ky}$ and $\mathrm{kz}$ are hydraulic conductivity values in $\mathrm{x}, \mathrm{y}, \mathrm{z}$ directions $[\mathrm{L} / \mathrm{T}]$; $\mathrm{h}$ the head $[\mathrm{L}]$; ss- Specific storage of the aquifer material [1/L]; $\mathrm{R} *$ is volume of recharge per unit volume of aquifer per unit time $[1 / \mathrm{T}]$; ss is specific storage. This represents the rate at which the water stored in the control volume is accumulated or deplete

The groundwater model was set up using the conceptual model described above: taking the western boundary of the model domain as a no flow boundary since it is a groundwater divide; the eastern boundary was also modelled as a no flow boundary since it is a lithologic boundary (the contact between the Nanka Sand and the Imo Shale Formations. The northern boundary was modelled as a head boundary using the head at Oguta Lake. The aquifer domain was modelled as a water table aquifer with 50 rows by 50 columns. The vertical anisotropy was taken into consideration by using different representative values for the vertical and horizontal hydraulic conductivity. Additionally, strata have a small true dip amount and were assumed to be horizontal. The model was calibrated and run against literature obtained observed data and the recharge values obtained from the modified UK Environment Agency spatial recharge model. The river and groundwater are assumed to be in full hydraulic connection. The digital elevation model was imported into GMS as the model surface elevation and the bottom was delineated using the data calculator tool in GMS. Furthermore, the steady state model served as the starting head for the transient model which was used to vary the groundwater level for the stability model. 


\subsection{Stability model}

Slope stability is usually assessed by calculating the safety factor, F. F is defined by the ratio of the shear strength of the soil along a potential failure surface to that required for the equilibrium of the soil mass. For an infinite slope, F can be expressed as:

$$
\mathrm{F}=\frac{\left(\mathrm{c}^{\prime}+\left[\gamma \mathrm{h} \cos ^{2} \alpha-\mathrm{uo}-\mathrm{u}(\mathrm{t})\right] \tan \emptyset\right)}{(\gamma \mathrm{h} \sin \alpha \cos \alpha)}
$$

where c' is the effective cohesion and $\varphi$ ' the angle of shearing resistance of the soil; $\gamma$ is the unit weight of the soil, which is assumed to be constant with depth; $h$ is the depth of the potential failure surface from the ground surface; $\propto$ is the slope angle; uo denotes the steadystate pore pressure at the failure surface (for an infinite slope with seepage parallel to the ground surface uo $=\gamma \mathrm{w}$ hw $\cos ^{2} \propto$, where $\gamma \mathrm{w}$ is the unit weight of water and hw is the height of the groundwater level with respect to the failure surface); and $\mathrm{u}(\mathrm{t})$ indicates the changes in pore pressure with time occurring at the failure surface owing to changes in the hydraulic conditions at the boundary.

The groundwater model was used to estimate the head values at each grid and then used in the calculation of the factor of safety for each grid transect to determine the minimum stability along each grid transect, using the Bishop's simplified method of slices (Eq. 3) -which focuses on the potential for movement. Although the method does not satisfy all conditions for equilibrium, it however, gives safety factor values with accuracy not worse than $+/-5 \%$ which is perfectly acceptable for practical purpose (Vinod et al., 2013)

$$
\text { Factor of safety }(\mathrm{FoS})=\frac{\left(\frac{\Sigma\left(\mathrm{c}^{\prime} \mathrm{b}+(\mathrm{W}-\mathrm{ub}) \tan \emptyset^{\prime}\right) 1}{\mathrm{~m}}\right)}{\Sigma \mathrm{W} \sin \alpha}-\text { (Eq. 3) }
$$

Where c' is cohesion $\left(\mathrm{kN} / \mathrm{m}^{2}\right)$; b is width of slice $(\mathrm{m}), \mathrm{W}$ is weight $(\mathrm{kN})$; $\mathrm{u}$ is water pressure (height of water above slice base $* 10)(\mathrm{kPa}) ; \emptyset=$ angle of shearing resistance (degree); and $\alpha=$ Angle of base of slices (degree).

OASYS SLOPE ${ }^{\circledR}$ - which works to solve the Bishop's equation was used to determine the minimum factor of safety along each slope transects (2 dimensional sections). By varying the water level through pumping from three hypothetical new wells, located at $-[289122 \mathrm{~m}$, $671425 \mathrm{~m}]$, [290904m, 670831m] and [286427m, 6691560m]-UTM. 300m3/day was assumed as the pump rate for each well and the proportional change in factor of safety was determined and contoured to get the risk map for the area. The interpretation of the significance of the factor of safety was based on BS 6013:2009 -code of practice for earthworks, British Standards Institute (Table 3).

Table 3: Values of factor of safety and their significance

\begin{tabular}{lll} 
FACTOR & OF & SIGNIFICANCE \\
SAFETY & \\
\hline Less than 1.0 & Unsafe \\
$\mathbf{1 . 0}-\mathbf{1 . 2}$ & Questionable safety \\
$\mathbf{1 . 3}-\mathbf{1 . 4}$ & Satisfactory for cuts, fills; questionable for dam \\
\hline
\end{tabular}


The literature derived geotechnical properties values (Table 4) were obtained from the works of Simpson et al (1999); Okagbue (1992); Ibeh (2011) and Ibeh (2013). Two geotechnical layers were delineated for the Nanka Formation.: the first is a combination of the Lateritic soil and the underlying sandy shale layer while, the second geotechnical layer is the main section of the Nanka Formation. A third geotechnical layer- the Imo Shale Formation which underlies the Nanka Formation - acts as the basement of the stability model. The lithologic interpretations of vertical electrical soundings (VES) for the basin area from Onwumesi et al. (1991), were used to delineate the geotechnical layers. Input data to the slope stability model are shown in Table 5. The surface elevation of the top geotechnical layer was obtained from the DEM. The Laterite - Sandy shale layer thickness was $20 \mathrm{~m}$ on average from the surface.

Table 4: Literature-derived geotechnical layers and their properties

\section{SHEAR STRENGTH PARAMETERS}

\begin{tabular}{|llll}
\hline GEOLOGY & UNIT WEIGHT $\left(\mathrm{kN} / \mathrm{m}^{3}\right)$ & PHI (Degree) & COHESION $\left(\mathrm{kN} / \mathrm{m}^{2}\right)$ \\
\hline Laterite and sandy shale & 16.5 & 12 & 5.5 \\
\hline Nanka Sand & 14.7 & 32 & 2 \\
\hline Imo shale & 16.5 & 21 & 16 \\
\hline
\end{tabular}

Table 5: Input to slope stability model

Input data $\quad$ Description

\begin{tabular}{|c|c|}
\hline Method of Analysis & British method of slices with analysis of circular slip surface \\
\hline Strength of the materials and unit weight of material & $\begin{array}{l}\text { specifying cohesion and an angle of shearing } \\
\text { resistance for each layer - derived from literature (see Table } 3.6 \text { for } \\
\text { data) }\end{array}$ \\
\hline Ground section (Geological layers) & $\begin{array}{l}\text { is built up by specifying each layer of material, from the surface } \\
\text { downwards, } \\
\text { as a series of } \mathrm{x} \text { and } \mathrm{y} \text { coordinates from VES interpretation }\end{array}$ \\
\hline Ground water profile & $\begin{array}{l}\text { A phreatic surface with hydrostatic pore pressure distribution input } \\
\text { as a series of } x \text { and } y \text { coordinates from the groundwater model } \\
\text { output }\end{array}$ \\
\hline Location of the grid of centres for circular failure & $\begin{array}{l}(700,350), 100 \text { grids with } 35 \mathrm{~m} \text { spacing in both } \mathrm{x} \text { and } \mathrm{y} \text { directions. } \\
\text { This is what appears as array dots above the transects stability } \\
\text { output }\end{array}$ \\
\hline Location and magnitude of surface loads & Not used \\
\hline Reinforcement & Not used \\
\hline
\end{tabular}

23 transects located along sections within and around landslide heads in the basin using the location list from the Nigerian National Intelligence Agency. This was used in combination with the digital elevation model to delineate the best transect section. Each transect is $140 \mathrm{~m}$ from the next (horizontal separation).

\section{Result and Discussion}

The study area slope angle (developed from the Digital Elevation Model (DEM) varies from zero degree to about 41.2 degrees in the Odo River Sub-Basin. Results of curvature analysis indicate that the spatial curvature range from -6.3 to 4.7. The negative values indicate concave zones while the positive values indicate convex zones. Furthermore, the land use/ land cover 
map developed from Landsat image shows the section of the basin covered by grass, tree, urban areas (houses), urban cultivated areas, and barren land (Figure 5).

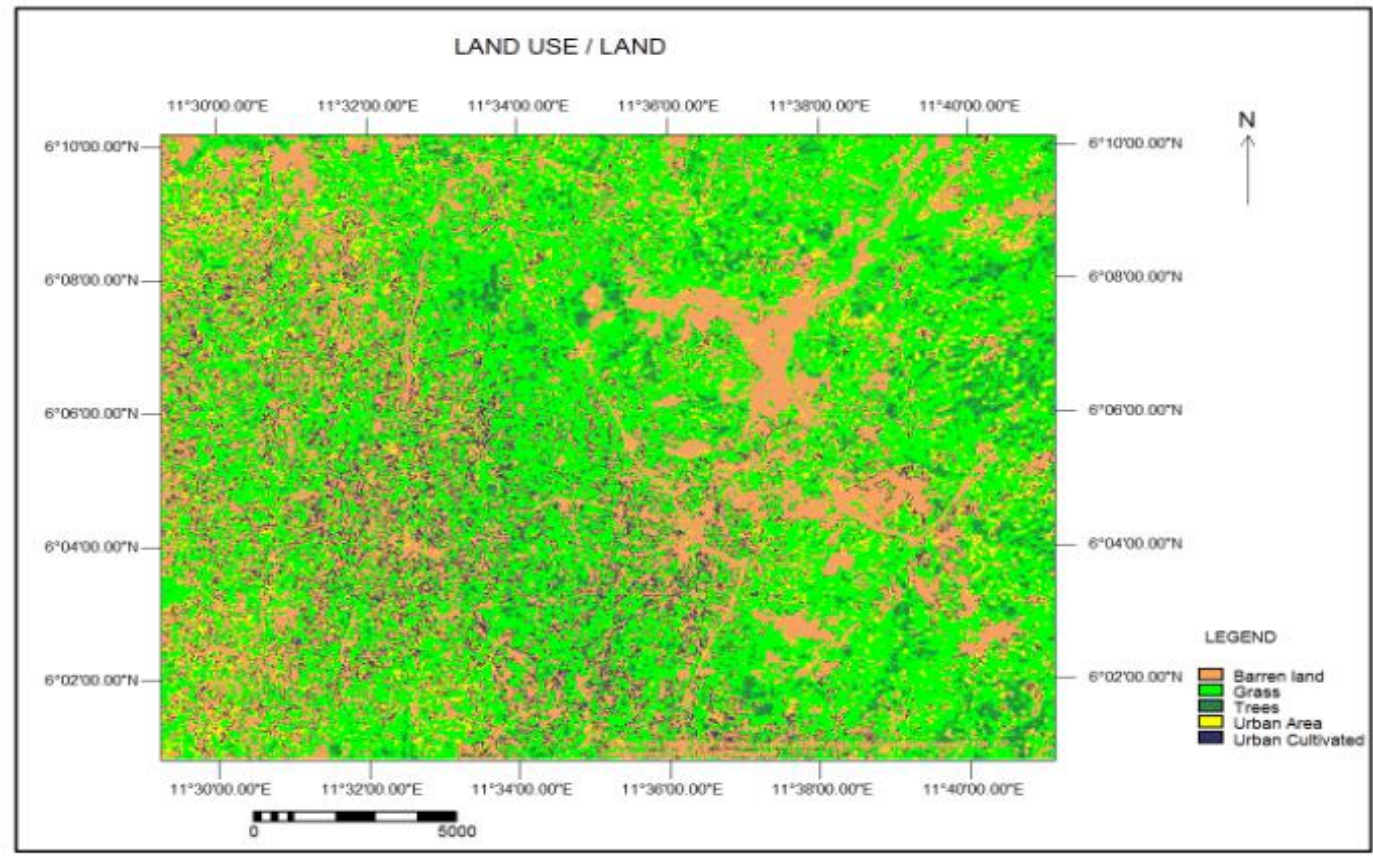

Fig. 5: Land Use/Land Cover map of the Odo River Sub-Basin, South Eastern Nigeria.

\section{7}

\subsection{Groundwater recharge model}

Comparing the average annual potential evapotranspiration $(1724 \mathrm{~mm} /$ year $)$ obtained in this study to the average annual evapotranspiration obtained by Egboka et al. (2006) $-1708 \mathrm{~mm} / \mathrm{year}$ -the result showed a reasonably comparable evapotranspiration (PE) value compared with PE calculated with the Penman method for the study area. The proportional percentage difference is $0.94 \%$ (less than $1 \%$ ). The average calculated PE value (using the Thonthwaite Method) compares well with published average PE value. Results of the model groundwater recharge gave an acceptable water balance of $0.08 \mathrm{~m}^{3}$ in the system between precipitation and other components of the water system.

\subsection{Groundwater model}

The steady state groundwater model was run with the average groundwater recharge of $0.001 \mathrm{~m} / \mathrm{d}$ over the year 1995 . Calibration of the model showed hydraulic conductivity (average of both the horizontal and vertical) $-0.2-\mathrm{m} / \mathrm{d}$ - is lower than the average value $(0.75)$ suggested by Egboka and Okpoko (1984). This is not unexpected since the study area is a smaller section of the whole area covered by the Nanka Formation and the hydraulic conductivity (K) of the Nanka Formation varies over the Formation. It is acceptable to have a reasonably different $\mathrm{K}$ value within a section of the Formation. Another possibility is that the $\mathrm{K}$ value derived by Egboka and Okpoko (1984) was biased to the sandy section of the Nanka Formation. The simulated hydraulic head for the steady state model was within $1 \mathrm{~m}$ of the observed average groundwater. On the other hand, no transient model calibration was done since there was no time series of head value for observation well available for the study area

\subsubsection{Groundwater model calibration}



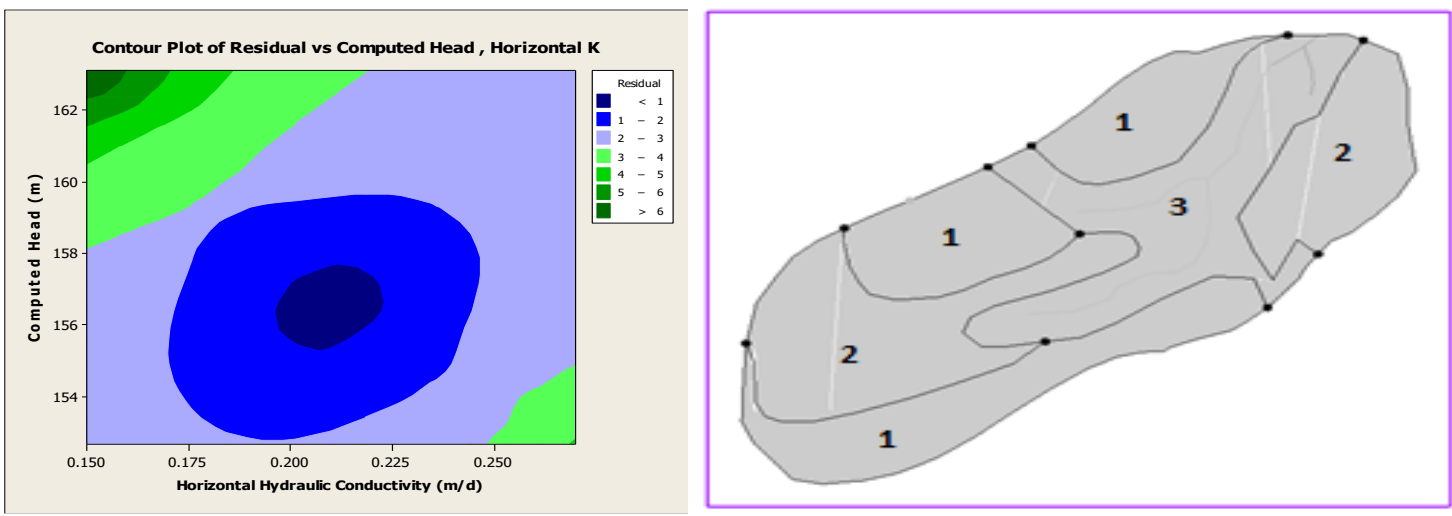

Table 6 below shows result of model calibration carried out by adjusting the horizontal hydraulic conductivity values within reasonable ranges to obtain an acceptable match between the simulated and observed heads in the observation borehole. The target for the steady state calibration was that the mean of the residuals should be close to zero, at most a value of 1 , to indicate that there is not much bias to simulated values. The horizontal and vertical hydraulic conductivity values $0.21 \mathrm{~m} / \mathrm{d}$ and $0.16 \mathrm{~m} / \mathrm{d}$ respectively gave the head value with the least mean residual for observation boreholes one and two. As the contour plot shows (Figure 6a) the horizontal hydraulic conductivity value that gave the residual value less than one 0.21 and this was used for the groundwater model.

Table 6: model calibration using Observation borehole

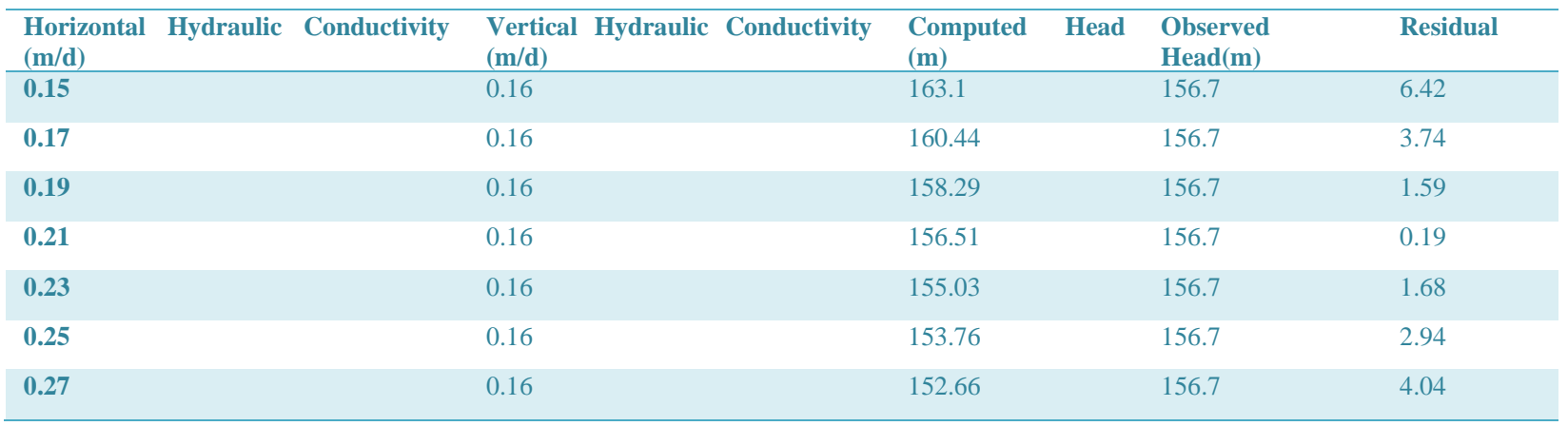

361

362

363

364

Figure 6a) Horizontal hydraulic conductivity versus computed head and residual; b) Delineated recharge zones

\subsubsection{Transient groundwater model (January through December 1995)}

The computed heads from the steady state calibrated model was used as the starting heads for the transient model. The output monthly recharge rate time series for the 3 recharge zones (figure $6 \mathrm{~b}$ ) from the spatial recharge model was input into the groundwater modelling software for the transient model simulation.12 stress periods with one-time step each were used. Figures $7 \mathrm{a}$ and $\mathrm{b}$ show groundwater heads before and after the one-year pumping from the 3 wells. 

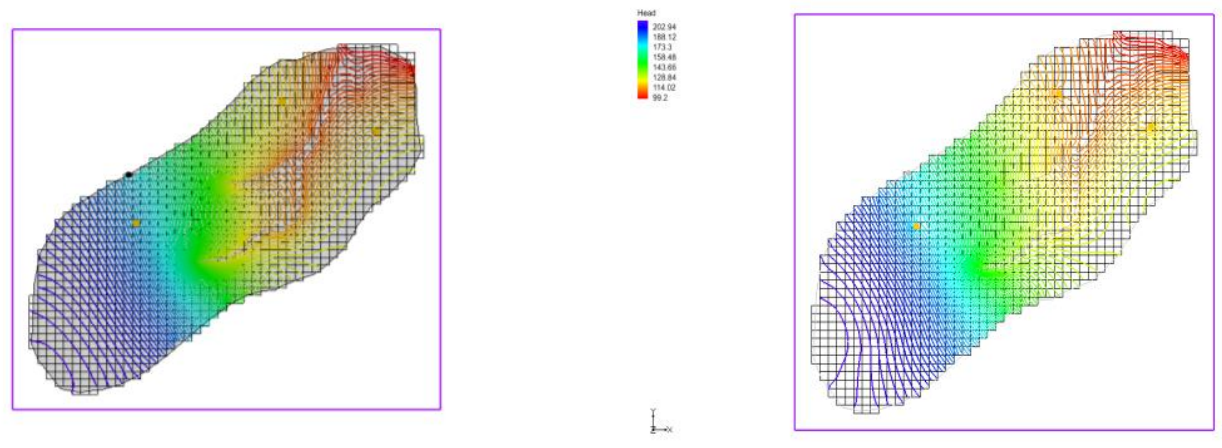

370 Figure 7: a) Groundwater level for static condition with (no pumping) b) Reduced groundwater level with three boreholes pumping at $300 \mathrm{~m}^{3} / \mathrm{d}$. (Yellow dots indicate location of wells)

\section{2}

\subsection{Stability Analysis}

It was hypothesized that a reduction in the groundwater level may significantly reduce the rate of expansion of gully erosion and landslide in the area. The present study was designed to determine the significance - if any- of the change in groundwater level in the study area has on its stability and the possibility of increasing the stability of the area by reducing the groundwater level in the study area. The most interesting finding was that reduction in groundwater level may significantly increase the stability of the Odo river sub-basin catchment.

All the 23 transects considered in the stability analysis, showed an increase in factor of safety except transect 21 which showed no change in factor of safety. Although proportional change in factor of safety was used in this study, of particular interest are the absolute values of transects 19 and 20 which increased from a minimum factor of safety values of 0.54 and 0.88 to 1.95 and 1.30 respectively. The values show improvement from an unstable condition (FOS $\leq 1$ ) to a stable condition (FOS $\geq 1.3$ ) - BS 6031 (2009).

The proportional change in factor of safety gives an indication of slope response that is less sensitive to errors in the assigned geotechnical properties than the absolute factor of safety values. The proportional change in factor of safety (with decrease in groundwater level by pumping from three wells located at $(289122 \mathrm{~m}, 671425 \mathrm{~m}),(290904 \mathrm{~m}, 670831 \mathrm{~m})$ and $(286427 \mathrm{~m}, 6691560 \mathrm{~m})-\mathrm{UTM}-$ at $300 \mathrm{~m} / \mathrm{d}$ each, varies over a much smaller range than to the change in factor of safety. On average the change in factor of safety increases by 0.87 , while the proportional change in factor of safety with decrease in groundwater level, was 0.56 (Table 7).

Table 7: Proportional change in Factor of safety across the 23 transects (OGWL -original groundwater level before pumping and LGWL - later groundwater level after pumping)

\begin{tabular}{lllll}
\hline TRANSECT & $\begin{array}{l}\text { MINIMUM } \\
\text { FOS AT OGWL }\end{array}$ & $\begin{array}{l}\text { MINIMUM } \\
\text { FOS AT LGWL }\end{array}$ & $\begin{array}{l}\text { CHANGE IN } \\
\text { FOS }\end{array}$ & $\begin{array}{l}\text { PROPORTIONAL } \\
\text { CHANGE IN FOS (A } \\
\text { RATIO) }\end{array}$ \\
\hline $\mathbf{1}$ & 1.54 & 2.21 & 0.67 & 0.44 \\
$\mathbf{2}$ & 1.69 & 3.68 & 1.99 & 1.18 \\
$\mathbf{3}$ & 3.29 & 4.11 & 0.82 & 0.25 \\
$\mathbf{4}$ & 1.39 & 1.71 & 0.32 & 0.23 \\
$\mathbf{5}$ & 1.38 & 1.79 & 0.41 & 0.30 \\
$\mathbf{6}$ & 1.74 & 2.56 & 0.82 & 0.47 \\
$\mathbf{7}$ & 2.78 & 3.88 & 1.10 & 0.39 \\
\hline
\end{tabular}




\begin{tabular}{lllll}
\hline $\mathbf{8}$ & 1.91 & 2.86 & 0.95 & 0.50 \\
$\mathbf{9}$ & 2.18 & 3.56 & 1.39 & 0.64 \\
$\mathbf{1 0}$ & 1.61 & 2.54 & 0.93 & 0.58 \\
$\mathbf{1 1}$ & 1.55 & 2.67 & 1.12 & 0.72 \\
$\mathbf{1 2}$ & 1.93 & 3.73 & 1.80 & 0.93 \\
$\mathbf{1 3}$ & 1.44 & 2.15 & 0.71 & 0.49 \\
$\mathbf{1 4}$ & 1.65 & 2.49 & 0.84 & 0.51 \\
$\mathbf{1 5}$ & 1.84 & 2.58 & 0.74 & 0.40 \\
$\mathbf{1 6}$ & 1.65 & 2.36 & 0.71 & 0.43 \\
$\mathbf{1 7}$ & 2.12 & 2.49 & 0.36 & 0.17 \\
$\mathbf{1 8}$ & 2.45 & 3.87 & 1.42 & 0.58 \\
$\mathbf{1 9}$ & $\mathbf{0 . 5 4}$ & $\mathbf{1 . 9 5}$ & 1.42 & 2.64 \\
$\mathbf{2 0}$ & $\mathbf{0 . 8 8}$ & $\mathbf{1 . 3 0}$ & 0.42 & 0.48 \\
$\mathbf{2 1}$ & 1.48 & 1.48 & 0.00 & 0.00 \\
\hline $\mathbf{2 2}$ & 1.33 & 1.72 & 0.39 & 0.30 \\
$\mathbf{2 3}$ & 4.07 & 4.66 & 0.59 & 0.14 \\
\hline
\end{tabular}

396 Figure 8 below shows a typical transect stability analysis using Oasys slope software. This gave 397 a minimum factor of safety of 1.4. Based on the adopted convention, the slope is satisfactorily stable. 1). The slip surface is usually some meters deep and may vary from about 10- 80 meters

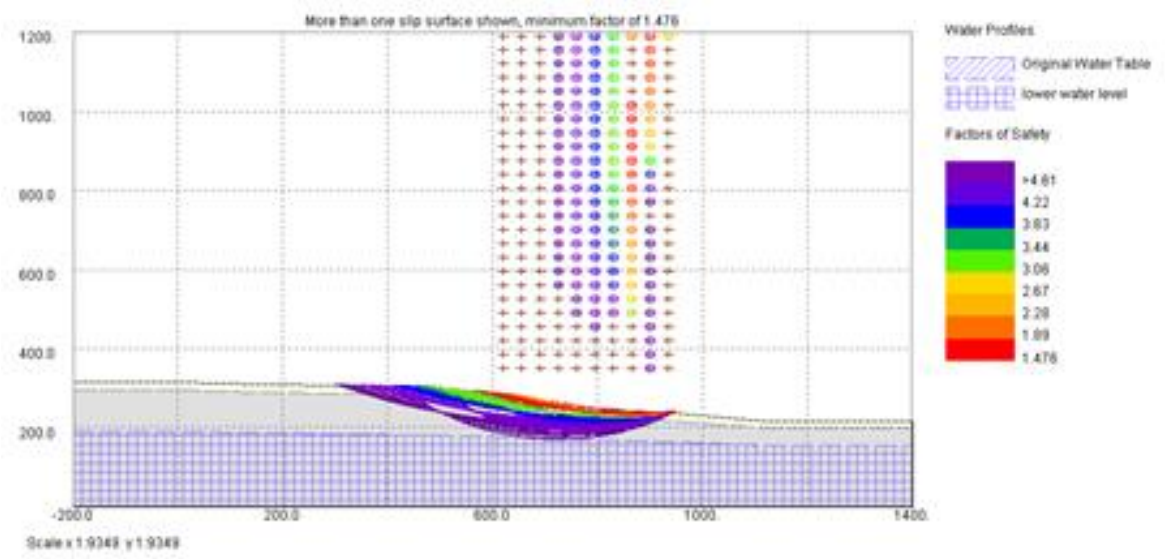

400 Figure 8: sample typical transect with minimum factor of safety 1.4.

Figure 9a below shows a comparison between the proportional changes in minimum factor of safety across the 23 transects to the average elevation across the 23 transects. Considering that in this area, topography has a major control on the groundwater level. Places where we have minimal proportional change in factor of safety are where we have relatively flat topography, correlated to areas with minimal head difference. However, in areas with very steep topography (large groundwater head difference) we have higher proportional increase in factor of safety. This further affirms that a decrease in groundwater level by some appreciable amount may help increase the stability of the Odo River Sub-Basin area. 


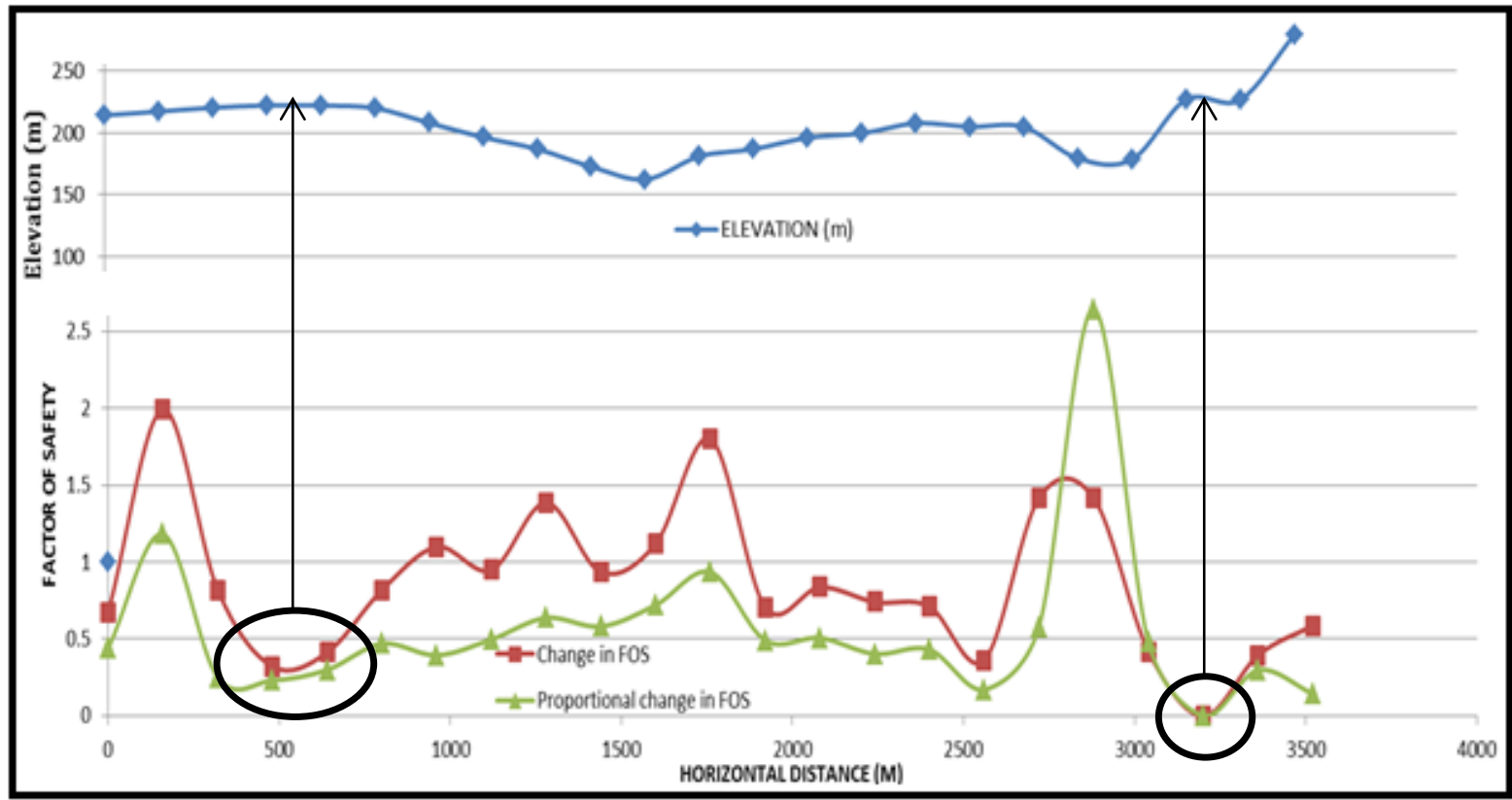

Fig. 9a: Comparison between the proportional changes in minimum factor of safety to the average elevation across the 23 transects

412 A comparison of the average change in groundwater level across the 23 transects (Figure 9b) with the proportional change in Factor of safety across the transects reveal that they have the same trend further suggesting that the proportional change in factor of safety is a consequence of change in groundwater on the area.

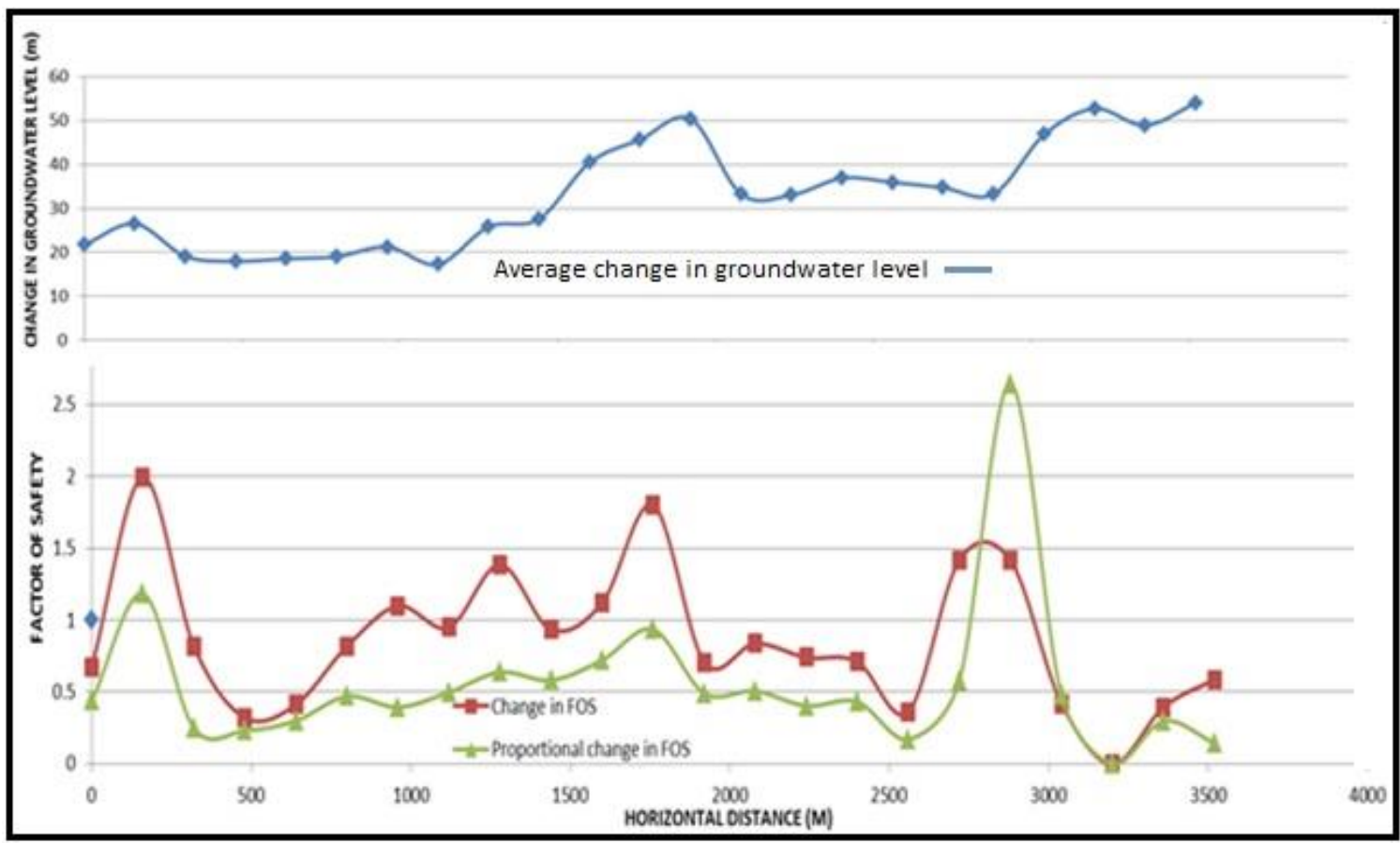

Figure 9b: Comparison of proportional change in FOS with average change in groundwater 
In this study, rise in groundwater level was found to have a significant effect on the stability of the Odo river catchment area and a reduction in the groundwater level through pumping may help increase the stability of the Odo River catchment south eastern Nigeria region as well as the help to provide water for the teeming population which currently lack access to potable water. However, there is the possibility of drying up lakes and reducing flow in rivers which might severely stress the ecosystem. A systematic analysis is needed of where to place the pumping wells in such a way that the reduction in groundwater level is achieved where needed and it does not significantly affect the ecosystem is needed.

The risk map (Fig. 10) developed in $\mathrm{ARCGIS}^{\circledR}$ using the Inverse Distance Weighting (IDW) interpolation tool shows that the areas with greatest proportional increase in factor of safety are within areas known to have experienced landslide. These areas exhibit very steep hydraulic gradient and topography. By reducing the groundwater in these areas by some meters, their stability may increase by an average of $56 \%$. Although the groundwater level reduction is huge and may have significant effect on the ecosystem, further studies is underway to investigate different scenarios of groundwater level reduction and their impact on water bodies around the study area.

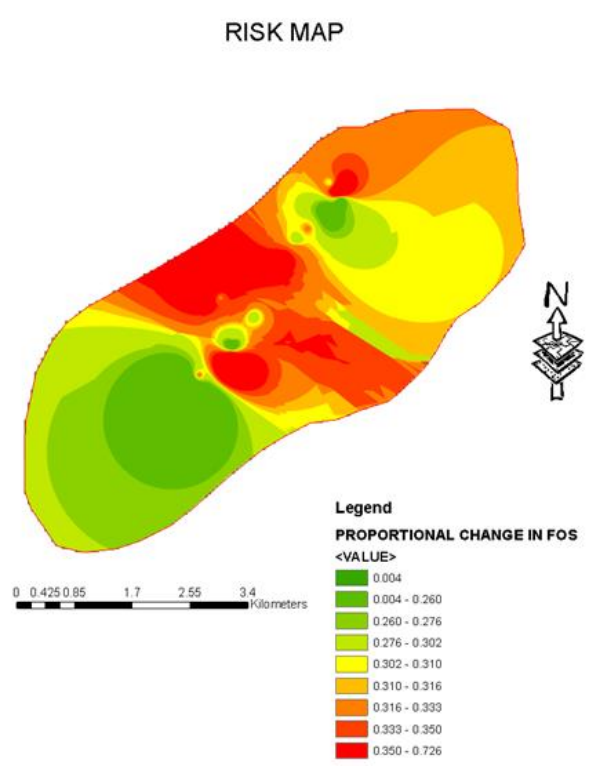

Figure 10: Gully and Landslide risk map of the Odo River Sub-Basin.

\subsection{Model Limitation}

There was limited data available for this study. Although it was shown that a reliable predictor of rainfall in the study area is the model consisting of latitude, longitude and elevation, there was however only one regional station with daily rainfall data. Data available for other stations were only annual rainfall data. Thus, it was not possible to reasonably interpolate the rainfall data down to a perfectly spatial daily rainfall data based on regression derived model. Daily rainfall time series obtained from a single regional weather station was assumed to be uniformly distributed over the domain. On the other hand, it is reasonably acceptable since: the study area is close to the weather station; is relatively small and is located about the same latitude with the weather station. Secondly, the spatial potential Evapotranspiration data, and soil data used for the spatial recharge estimation were also assumed to be uniform over the study area. Soil is one of the most variable materials on earth, and their properties vary in time 
and space. This is however part of the reason why the absolute values of the Factor of safety was not used but rather the proportional change in factor of safety. In addition, there was no transient observation borehole data to calibrate the groundwater model. Furthermore, twodimensional stability models imply plain strain in the vertical direction but the effect of this on the value of change in factor of safety is unknown. This study did not consider surcharge as an addition to the driving force neither did it consider root and plants strength. It is important to also note that pumping might result in some ecological challenges, since it may reduce the amount of water in lake and rivers except the pumping wells are properly located in areas where they will have minimal effect on the ecological system. Finally, the effect of suction in unsaturated soils was not considered in this study and LOCOUPSTAB model framework does not account for the analysis of post-failure stage and run-out of a landslide, such stages require the use of advanced numerical technique as earlier stated in the introduction section. Overall the simplifying assumptions that were made are reasonably acceptable to draw workable conclusion.

\subsection{CONCLUSION}

The effect of changing groundwater level on the stability of soil in the Odo River sub-basin, within the Agulu -Nanka gully erosion and Landslide complex, was investigated using the modified deterministic LOCOUPSTAB model framework (loosely coupled stability model framework). It was observed that reducing groundwater level by pumping from wells may possibly increase the stability of the landmass of the Odo river basin catchment area by an average proportional increase in factor of safety value of 0.56 - a value which can take a slope from and unstable condition to a satisfactorily stable condition.

Using Geographic information system and the calculated proportional change in factor of safety, a stability risk map was developed for the case study area: the Odo river sub-basin. Overall, the LOCOUPSTAB model framework has been shown to be useful in evaluation of the effect of changing water level on the stability of slope in the study area. This has particularly been useful in an area with data availability challenge. It is important to point out that although, useful information can be obtained even based on imperfect data availability; model output should be interpreted carefully in the light of parameter uncertainty. It is important to point out that the LOCOUPSTAB model framework does not account for the analysis of post-failure stage and run-out of a landslide, such stages require the use of advanced numerical technique as earlier stated in the introduction section

The study also showed that groundwater in the study area is both a resource and a nuisance, in that, it has shown that in a community with little access to potable water, pumping water from the groundwater reservoir can help provide water for the populace and at the same time increase the stability of the landmass on which they live. There is however the need to assess the impact of the groundwater level reduction on the waterbodies around the area to ensure sustainability of the ecosystem. The research provides a base for future studies on the control of gully erosion and landslide as well as the provision of groundwater resources for the teaming population of the Agulu-Nanka area.

\section{ACKNOWLEDGEMENTS}

I appreciate my supervisors Dr. Geoff Parkin and Dr. James Bathurst who for their supervision. I also thank Prof. Chris Kilsby for his assistance in helping me through Prof. Mbajiorgu to 
obtain the rainfall data used in this study and for his advice. This work was supported by the Commonwealth scholarship commission under the Commonwealth Shared Scholarship.

\section{REFERENCE}

Alonso, E.E.; Gens, A.; Delahaye, C.H. 2003. Influence of rainfall on the deformation and stability of a slope in overconsolidated clays: a case of study. Hydrogeology J 11, 174192, DOI: $10.1007 / \mathrm{s} 10040-002-0245-1$

Anderson, M.P. \&Woessner, W.W. 1992. Applied groundwater modelling: Simulation of flow and advective transport. Academic Press Inc., San Diego, 381pp.

Anejionu, O.C.D., Nwilo, P.C., and Ebinne, E.S. (2013). Long Term Assessment and Mapping of Erosion Hotspots in South East Nigeria. TSO 3B - Remote Sensing for Land use and Planning - 6448, FIG Working Week, 2013.

Bankole, S.A. and Ola-Buraimo, A.O., 2017. Biostratigraphy and palaeoenvironment of deposition of Nsukka Formation, Anambra Basin, southeastern Nigeria. Journal of Palaeogeography, 6(1), pp.45-59.

BS 6031. 2009. Code of practice for earthworks, British Standards Institute.

Chung C.F., Fabbri, A.G. Westen, C.J.1995. Multivariate regression analysis for landslide hazard zonation. Geographical Information Systems in Assessing -Natural Hazards, 5 pp107-133.

Conte, E. A. Troncone 2012. Stability analysis of infinite clayey slopes subjected to pore pressure changes. Geotechnique, 62(1): 87-91. DOI: 10.1680/geot.10.T.002.

Conte, E. A. Donato, L. Pugliese, A. Troncone 2018. Analysis of the Maierato landslide (Calabria, Southern Italy). Landslides, DOI: 10.1007/s10346-018-0997-x

Conte, E., Pugliese, L., Troncone, A., 2019. Post-failure stage simulation of a landslide using the material point method. Engineering Geology, Volume 253, 149-159. DOI: 10.1016/j.enggeo.2019.03.006

Crosta, G.B., Imposimato, S., Roddeman, D.G., 2003. Numerical modelling of large landslide stability and runout. Nat. Hazards Earth Syst. Sci. 3 (6), 523-538.

Dai F. C., Lee C. F., \& Wang S. J., 2003. Characterization of rainfall-induced landslides International Journal of Remote Sensing, 24 (23), 4817-4834.

Egboka, B. C. E., and Okpoko, E, I. (1984). Gully erosion in the Agulu-Nanka region of Anambra State, Nigera. Challenges in African Hydrology and Water Resources (Proceedings of the Harare Symposium). IAHS Publ. no. 144. http://iahs.info/redbooks/a144/iahs_144_0335.pdf (accessed on 12th September 2012). Ezemonye 
Egboka, B. C. E., Nfor,B.N and Banlanjo E.W 2006. Water budget analysis of Agulu Lake in Anambra State, Nigeria. J.App. Sci. Environ. Mgt. 10 (3), pp 27-30

Egboka B.C.E., \& Nwankwo G.I. 1984. The hydrogeological and geotechnical parameters as agents for gully -type erosion in the Rain Forest Belt of Nigeria. Journal of African Earth Sciences 3(4), pp. $417-425$

European Digital Achive of soil maps. 2013: http://eusoils.jrc.ec.europa.eu/esdb_archive/ eudasm/africa/lists/s1_cng.htm. (Accessed 05/05/2013)

Hansen A., 1984. Landslide hazard In: Brunsden D., and Prior D.B, (Editors), Slope instability, Wiley, New York, 523-602

Haque, U., Blum, P., Da Silva, P.F., Andersen, P., Pilz, J., Chalov, S.R., Malet, J.P., Auflič, M.J., Andres, N., Poyiadji, E. and Lamas, P.C., 2016. Fatal landslides in Europe. Landslides, 13(6), pp.1545-1554.

Howes, M., Wortley, L., Potts, R., Dedekorkut-Howes, A., Serrao-Neumann, S., Davidson, J., Smith, T. and Nunn, P., 2017. Environmental sustainability: a case of policy implementation failure? Sustainability, 9(2), p.165.

Ibeh, U.C. 2011. Geotechnical properties of samples from Nanka and Uniben gullies and their bearing on gully erosion. BSc. Thesis, University of Benin

Ibeh, U.C. 2013. Deciphering gully erosion \& landslide in the Odo River Sub- Basin: Integrating hydrological, hydrogeological, and geotechnical models through GIS. MSc. Thesis, University of Newcastle, 103p

Igbokwe, J. I. Akinyede, J. O., Dang, B., Alagac, T., Onoa, M. N., Nnodu, V. C., Anike, L. O. (2008). Mapping and monitoring of the impact of gully erosion in Southeastern Nigeria with satellite remote sensing and Geographic Information System. The International Archives of the Photogrammetry, Remote Sensing and Spatial Information Sciences, 37, B8. Beijing.

Igwe C.A. (2012). Gully Erosion in Southeastern Nigeria: Role of Soil Properties and Environmental Factors, Research on Soil Erosion, Danilo Godone, Silvia Stanchi, IntechOpen, DOI: 10.5772/51020. Available from: https://www.intechopen.com/books/research-on-soil-erosion/gully-erosion-insoutheastern-nigeria-role-of-soil-properties-and-environmental-factors (Accessed 02/04/2013)

Lee, S., Hyung, J., Sun, J., \& Park, H. J. (2004). Determination and application of the weights for landslide susceptibility mapping using an artificial neural network. Engineering Geology, 289302.

Liu, Q.Q. and Li, J.C., 2015. Effects of water seepage on the stability of soil-slopes. Procedia IUTAM, 17, pp.29-39. 
MET OFFICE 2013. http://www.metoffice.gov.uk/research/climate/climate-monitoring/landand atmosphere/surface-station-records (Accessed 02/04/2013)

Neuhauser B. and Terhorst B. 2007 Landslide Susceptibility using 'weight of evidence', applied to a study area at the Jurassic escarpment (SW-Germany). Geomorphology 86 pp. 12-24

OASYS SLOPE GUIDE

(2012). http://www.oasyssoftware.com/media/Manuals/Latest_Manuals/slope19.0_manual.pd f) (Assessed on 04/04/2013)

Okagbue C.O. 1992. The 1988 Nanka landslide, Anambra state, Nigeria. Bulletin of the International Association of Engineering Geologist 46, pp.80-87

Okoro EI, Egboka BCE, Onwuemesi AG (2010b) Evaluation of the aquifer characteristics of the Nanka sand using hydrogeological method in combination with vertical electric sounding (VES). J Appl Sci Environ Manag 14(2):5-9

Onwumesi, A.G., Egboka, B.C.E., Orajaka, I.P., \& Emenike, E.A. 1991. Implications of hydrogeophysical investigations of the Agulu-Nanka gullies area of Anambra State of Nigeria, Journal of African Earth Sciences, 13(3•4), pp. 519-526.

Safaei, M., Omar, H., Huat , B.K., Yousof, Z.B.M., Ghiasi V. 2011. Deterministic Rainfall Induced Landslide Approaches, Advantage and Limitation, EJEG, 16, pp. 1619-1650

Shaw E.M. 1994. Hydrology in practice. Third Edition. Chapman and Hall, London, 569pp

Schiller, M., and Wynne S., 2010. The effect of declining water level on the stability of riverbank slopes. https://soilvision.com/.../Schiller\%20Wynne\%20(2010) \%20Conference\%20Paper.pdf (Accessed 02/04/2013)

Simpson, F., Hudec, P.P., Akpokodje, E., Umenweke, M., Ondrasik, M. 1999. Gully erosion of Coastal Plain Sediments of Nigeria, Proceedings of eight International Congress, International Association of Engineering Geologist and the Environment, 21-25, September, Vancouver, Canada. pp. 1835-1841

Singhroy, V., Glenn, N. and Ohkura, H., 2004. Landslide hazard team report of the CEOS disaster management support group. CEOS Disaster Information Server, [URL:] http://www.ceos.org/pages/DMSG/2001Ceos/Reports/landslide.html (2004-03-05).

Tembergen B., Mohammed, M.U. Korme, T. 2001. Natural hazard assessment using GIS and remote sensing methods, with reference to the landslide in the Wondogenet area, Ethiopia. Physics and Chemistry of the Earth, Part C: Solar,Terrestrial and Planetry Science, 26(9), 665-675.

Uma K.O., and Onuoha K. M. (1997) Hydrodynamic flow and formation pressures in the Anambra basin, southern Nigeria, Hydrological Sciences Journal, 42:2, 141-154 
Vinod M.P., Jignesh B.P., Amol K.P. 2013. Comparative study of advanced two-dimensional methods of slope stability analysis. International Journal of Advanced Technology in Civil Engineering, 2 (1), pp. 92-95.

Wang, H.D., Yang, Q., Pan, S.H., Ding, W.C. and Gao, Y.L., 2012. Research on the impact of the water-level-fluctuation zone on landslide stability in the Three Gorges Reservoir Area. In Applied Mechanics and Materials (Vol. 188, pp. 37-44). Trans Tech Publications.

Wu, X. and Niu, R., 2011. Effects of groundwater level fluctuations on deformation of Baishuihe landslides, China. In Geoinformatics, 2011 19th International Conference on (pp. 1-4). IEEE.

Yerro, A., Alonso, E. E., and Pinyol, N. M. 2016. Run-out of landslides in brittle soils. Computers and Geotechnics, 80, 427-439. DOI: 10.1016/j.compgeo.2016.03.001

Zhang WM, Chen LY. 2005 Effect of water table on soil slope stability. Chin J. Rock Mech. Eng.24, 5319-5322. 